\title{
Study of an evaluation index system of well-off water conservancy in Yunnan Province
}

\author{
CHUNXIAO CHANG ${ }^{1}$, ZHONGHUI WEN ${ }^{1}$, LONGCANG SHU ${ }^{1}$, CHENGPENG LU ${ }^{1}$, \\ SHIXIANG GU², JIANGUANG SU², MENG HE ${ }^{1}$ \& KUNDONG XING ${ }^{1}$ \\ 1 College of Hydrology and Water Resources, Hohai University, Nanjing, 210098, China \\ wenzh2812@sina.com \\ 2 Yunnan Institute of Water and Hydropower Engineering Investigation, Design and Research, Kunming, 650021, China
}

\begin{abstract}
To achieve good water conservancy under the well-off society before 2020, the future water conservancy planning is undergoing in Yunnan Province. In this study, by analysing the research results of domestic relevant water evaluation index systems and combining this with the water conservancy construction key of Yunnan Province, an unique evaluation index system was proposed to evaluate the welloff water conservancy level of Yunnan Province. It is composed of three levels which are the target layer, criterion layer and index layer. And the criterion layer includes six systems, namely flood control and drought relief mitigation, reasonable allocation of water resources, highly effective water utilization, water source protection and river health security, water management and securing of water development. The analytic hierarchy process (AHP) was used to determine the weight of each index. According to the present situation of water development and the related water conservancy planning in Yunnan Province, the target value of each index and evaluation standards are put forward for Yunnan Province in 2020. The results show that the evaluation results are consistent with the actual condition of water development in Yunnan Province and can be used to examine the effects of well-off water conservancy planning.
\end{abstract}

Key words well-off water conservancy; index system; evaluation; Yunnan Province; well-off society

\section{INTRODUCTION}

As a basic industry of the national economy and important infrastructure of social and economic development, water conservancy should be developed in advance to support and ensure the smooth implementation of the comprehensive building of a well-off society. Water conservancy should guarantee the safety of water supply, flood control and the ecological environment, and is directly related to the long-lasting prosperity of a country and ability for people to live and work in peace and contentment. With the gradual societal development, water plays an important role in maintaining, protecting, improving and creating an excellent ecological environment and providing people with a pleasant environment for producing and living.

Synchronized with the national goal, Yunnan Province strives to achieve a well-off society comprehensively before 2020 . New requirements for water conservancy are proposed. Under this background, the well-off water conservancy construction planning is carried out in Yunnan Province. In order to provide the basic guarantee for the realization of the well-off society in Yunnan Province, a well-off water conservancy under the well-off society should be built. Therefore, combining with the goal of well-off water conservancy planning in Yunnan Province, the evaluation index system of well-off water conservancy is built for Yunnan Province and is used to evaluate the level of well-off water conservancy development and guide the well-off water construction in the future.

Well-off is a development stage of life between subsistence and wealthy and well-off society is a new concept reflecting the overall coordination of economic and social development. Well-off water conservancy in general may be defined as using the foundation, safety and comfort of the water conservancy to support and protect the realization of the well-off society. It is a developing process and a phase objective of water conservancy modernization. In recent years, domestic scholars have carried out extensive research on the index system of water conservancy modernization. For example, Tong et al. (2012) proposed that water conservancy modernization evaluation can be divided into comprehensive evaluation and individual evaluation. She used the analytic hierarchy process (AHP) which combines qualitative and quantitative analysis to solve the multi-level and multi-objective evaluation of water conservancy modernization in the complex system. Zhang et al. (2004) proposed the index system of water conservancy modernization in 
Shanghai suburb according to the principal component analysis (PCA).Yu et al. (2013) and Ou et al. (2012) adopted the PCA in the study of water conservancy modernization index system in Jiangsu. They also used the fuzzy clustering analysis method for further screening the selection index and simplified the index system on the basis of the primary index set. At present, the study of the evaluation index system for well-off water conservancy is still rare. But the related research results of the water conservancy modernization index system can provide a lot of reference to carry out an evaluation index system of well-off water conservancy in Yunnan Province.

\section{CURRENT SITUATION OF WATER DEVELOPMENT IN YUNNAN PROVINCE}

With the rapid advance of urbanization and industrialization, global warming, frequent extreme weather, intensified floods and droughts threaten economic and social development leading to a higher requirement for the safety of flood control, water supply and water ecological environment protection, highlighting many weak links of water conservancy in Yunnan Province:

(a) The weak link of the flood control and drought relief is prominent in that the ability of effectively coping with climate change and resisting major flood is not strong.

(b) The water conservancy infrastructure of the rural people's livelihood is weak. The tasks of irrigation and water conservancy construction are large.

(c) The water shortage of urban areas is becoming increasingly prominent, and the water used for ecological environment and agricultural is being squeezed out.

(d) The way of extensive utilization of water resources has not changed fundamentally. The waste of water resources is still serious.

(e) The situation of water environment pollution is grim. The pressure to protect the lakes and water ecology is great.

(f) There are many institutional barriers that restrict the development of water conservancy. The guarantee ability of water conservancy development still needs to be improved.

\section{ESTABLISHMENT OF THE INDEX SYSTEM}

\subsection{The framework of index system}

At the Central Water Conference in 2011, President Hu proposed that "We should build four systems which are the flood control and drought relief system, rational allocation and effective use of water resources system, water resources protection and river and lake health security system, the system and mechanism conducive to the development of water conservancy science to 2020". To make the index system better adapted when using AHP, the rational allocation and effective use of water resources system is divided into rational allocation system and efficient utilization system, and the system and mechanism conducive to the development of water conservancy science is divided into management system and guarantee system. Finally, the index system consisting of six systems: flood control and drought relief mitigation, the reasonable allocation of water resources, highly effective water utilization, water source protection and river health security, water management and securing of water development, is proposed. In this study, the index system is composed of three levels. The three levels are target layer, criterion layer and index layer. The target layer is a single goal; the criterion layer is consisted of the six big systems. There are some specific indexes under each criterion layer. The hierarchy of the index system is shown in Fig. 1.

\subsection{The selecting principle for well-off water evaluation indexes}

Scientific selection of well-off water evaluation indexes is our objective. The index system of well-off water conservancy should be based on the current situation of the development of water conservancy in Yunnan Province, combined with the relevant requirements of the well-off society. In addition, the principle of being systematic, scientific, practical and concise should be followed, mainly including the following aspects: combination of systemic and independence, combination of representative and comprehensive, combination of scientific and operability, combination of dynamic and static and combination of regional and normative. 


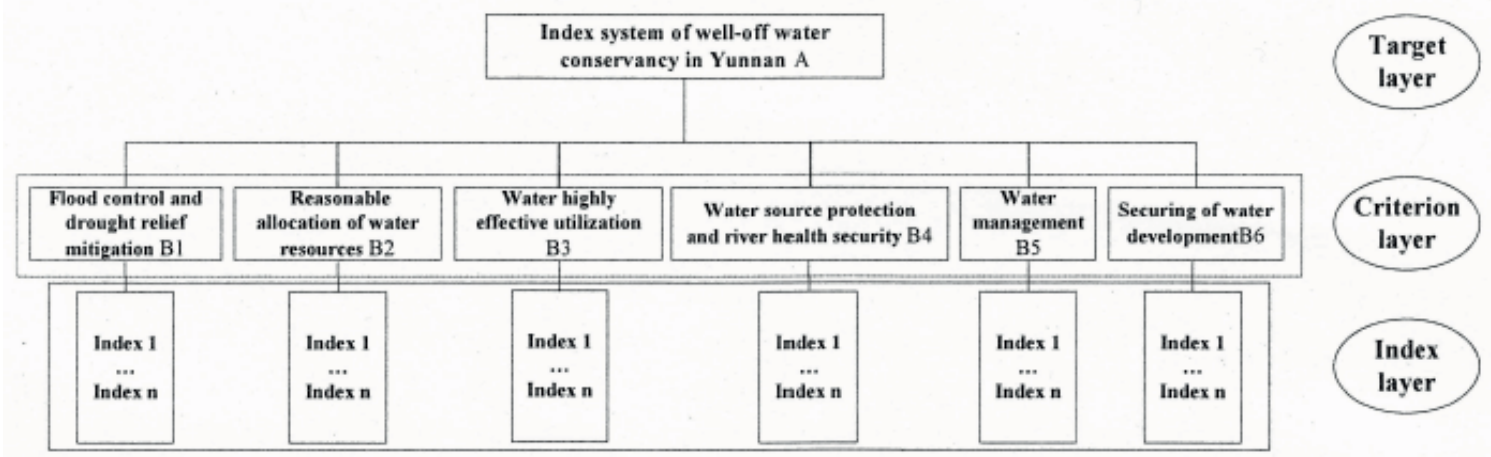

Fig. 1 Index system structure of well-off water conservancy in Yunnan.

\subsection{The selection of indexes}

The selection of indexes is the foundation of the construction of evaluation system. Reasonable selection of the evaluation indexes effects the accuracy of the evaluation results. At present, many domestic experts and scholars have conducted in-depth research on the evaluation index system of water conservancy modernization and well-off water conservancy, forming the alternative allround indicators. At first, the indexes should be selected according to circumstances by following the selection principle of well-off water evaluation indexes and combining with the present situation of water development and the water conservancy construction key of Yunnan Province. Then, necessary additions and deletions should be made to optimize the primary indicators according to the views of the local water experts. Finally, the index system of well-off water conservancy in Yunnan Province is composed of six systems and 37 indicators (Table 1).

To strengthen the monitoring and guidance in the key areas and highlight the role and status of important indicators, 37 indicators are divided into 10 mandatory indicators, 13 assessment indicators and 14 reference indicators according to whether there is a mandatory requirement or clear assessment standards to indexes in the planning period. The classification results are shown in Table 1.

\subsection{Determining the target values}

The target values of evaluation indexes are the standards to determine whether the water conservancy construction in Yunnan Province has achieved the well-off water level. In addition, scientific and reasonable target values are also important bases for the evaluation of well-off water conservancy in Yunnan Province.

To determine the target values of the 37 indexes of well-off water, this study not only consults the content of The twelfth five-year plan of water development in Yunnan, Yunnan integrated water resources planning, The twelfth five-year plan of water-saving society in Yunnan and other relevant planning, but also refers to the water conservancy social development goals of building a well-off society in China and the level of development of domestic and foreign advanced areas. Then, combined with the status of water development in Yunnan Province, the target values of 37 evaluation indexes are determined, as shown in Table 1. The methods of determining target values are different according to the different types of indexes:

Mandatory indexes For mandatory indexes, the target values are determined according to the target, which the national or provincial standards mandatory are required to meet.

Assessment indexes For assessment indexes, the target values are determined according to the combination of the assessment objectives of relevant planning and the current situation of water development level in Yunnan Province.

Reference indexes For reference indexes, the target values are determined according to the combination of theoretical analysis and the current situation of water development level in Yunnan Province. 
Table 1 The index system for well-off water conservancy in Yunnan.

\begin{tabular}{|c|c|c|c|c|c|c|c|}
\hline System & Number & Index & & Index type & & Weight & Target value \\
\hline $\begin{array}{l}\text { Flood } \\
\text { control and } \\
\text { drought } \\
\text { relief } \\
\text { mitigation }\end{array}$ & $\begin{array}{l}1 \\
2 \\
3 \\
4 \\
5\end{array}$ & $\begin{array}{l}\text { Drought and flood disaster loss rate } \\
\text { Compliance rate of flood control } \\
\text { New dikes and revetment length } \\
\text { Completion rate of dangerous reservoir reinforcement } \\
\text { Mountain torrents disaster prevention site density }\end{array}$ & & assessment & $\begin{array}{l}\text { reference } \\
\text { reference } \\
\text { reference }\end{array}$ & $\begin{array}{l}3 \\
4 \\
2 \\
2 \\
4\end{array}$ & $\begin{array}{l}0.8 \% \\
90 \% \\
3500 \mathrm{~km} \\
100 \% \\
20 \mathrm{~km}^{2} / \text { station } \\
\end{array}$ \\
\hline $\begin{array}{l}\text { Reasonable } \\
\text { allocation of } \\
\text { water } \\
\text { resources }\end{array}$ & $\begin{array}{l}6 \\
7 \\
8 \\
9 \\
10 \\
11 \\
12 \\
13 \\
14 \\
15 \\
16\end{array}$ & $\begin{array}{l}\text { Penetration of rural water supply } \\
\text { Compliance rate of rural drinking water safety } \\
\text { The rate of effective irrigation } \\
\text { New effective irrigation area } \\
\text { Penetration of urban water supply } \\
\text { Compliance rate of urban drinking water safety } \\
\text { New water storage capacity } \\
\text { New water supply capacity } \\
\text { The proportion of water storage project of water supply } \\
\text { Number of five small water project for } 100 \text { people in the mountain } \\
\text { The rate of reservoir dredging }\end{array}$ & mandatory & $\begin{array}{l}\text { assessment } \\
\text { assessment } \\
\text { assessment } \\
\text { assessment } \\
\text { assessment }\end{array}$ & $\begin{array}{l}\text { reference } \\
\text { reference } \\
\text { reference }\end{array}$ & $\begin{array}{l}3 \\
4 \\
2 \\
3 \\
2 \\
4 \\
3 \\
3 \\
2 \\
2 \\
1\end{array}$ & $\begin{array}{l}80 \% \\
100 \% \\
50 \% \\
1.15 \text { million mu } \\
95 \% \\
100 \% \\
4 \text { billion } \mathrm{m}^{3} \\
5 \text { billion } \mathrm{m}^{3} \\
45 \% \\
15 \\
25 \%\end{array}$ \\
\hline $\begin{array}{l}\text { Water highly } \\
\text { effective } \\
\text { utilization }\end{array}$ & $\begin{array}{l}17 \\
18 \\
19 \\
20 \\
21 \\
22 \\
23 \\
24\end{array}$ & $\begin{array}{l}\text { Water total volume control } \\
\text { Water consumption per } 10000 \text { Yuan of value-added by industry } \\
\text { The recycling rate of industrial water } \\
\text { Penetration of urban water-saving appliances } \\
\text { Leakage rate of urban water supply pipe network } \\
\text { Water-saving irrigation rate } \\
\text { New efficient water-saving irrigation area } \\
\text { Effective utilization coefficient of irrigation water }\end{array}$ & $\begin{array}{l}\text { mandatory } \\
\text { mandatory }\end{array}$ & $\begin{array}{l}\text { assessment } \\
\text { assessment } \\
\text { assessment }\end{array}$ & $\begin{array}{l}\text { reference } \\
\text { reference }\end{array}$ & $\begin{array}{l}4 \\
4 \\
2 \\
1 \\
2 \\
2 \\
2 \\
4\end{array}$ & $\begin{array}{l}21.5 \text { billion } \mathrm{m}^{3} \\
65 \mathrm{~m}^{3} \\
95 \% \\
90 \% \\
15 \% \\
50 \% \\
8 \mathrm{million} \mathrm{mu} \\
55 \%\end{array}$ \\
\hline $\begin{array}{l}\text { Water source } \\
\text { protection } \\
\text { and river } \\
\text { health } \\
\text { security }\end{array}$ & $\begin{array}{l}25 \\
26 \\
27 \\
28 \\
29 \\
30 \\
31\end{array}$ & $\begin{array}{l}\text { Water quality compliance rate of water functional areas } \\
\text { Water quality compliance rate of centralized drinking water source } \\
\text { The degree of soil erosion } \\
\text { Completion rate of key water ecological restoration and protection } \\
\text { project } \\
\text { Restoration rate of rural river } \\
\text { Restoration rate of rural pond and dam } \\
\text { Rural sewage treatment rate }\end{array}$ & $\begin{array}{l}\text { mandatory } \\
\text { mandatory }\end{array}$ & assessment & $\begin{array}{l}\text { reference } \\
\text { reference } \\
\text { reference } \\
\text { reference }\end{array}$ & $\begin{array}{l}4 \\
4 \\
3 \\
1 \\
1 \\
1 \\
1\end{array}$ & $\begin{array}{l}75 \% \\
100 \% \\
32 \% \\
80 \% \\
40 \% \\
35 \% \\
36 \%\end{array}$ \\
\hline $\begin{array}{l}\text { Water } \\
\text { management }\end{array}$ & $\begin{array}{l}32 \\
33 \\
34 \\
35 \\
\end{array}$ & $\begin{array}{l}\text { The monitoring rate of water function areas } \\
\text { The monitoring rate of centralized drinking water source } \\
\text { Automatic monitoring rate of precipitation and water level in station } \\
\text { Water monitoring rate of quantity and quality of city boundary river }\end{array}$ & $\begin{array}{l}\text { mandatory } \\
\text { mandatory }\end{array}$ & $\begin{array}{l}\text { assessment } \\
\text { assessment }\end{array}$ & & $\begin{array}{l}5 \\
4 \\
3 \\
3\end{array}$ & $\begin{array}{l}100 \% \\
90 \% \\
100 \% \\
100 \%\end{array}$ \\
\hline $\begin{array}{l}\text { Securing } \\
\text { development }\end{array}$ & $\begin{array}{l}36 \\
37\end{array}$ & $\begin{array}{l}\text { The information level of water science and technology } \\
\text { Compliance rate of talent structure }\end{array}$ & mandatory & & reference & $\begin{array}{l}2 \\
3 \\
\end{array}$ & $\begin{array}{l}60 \% \\
80 \%\end{array}$ \\
\hline
\end{tabular}




\subsection{Weight analysis of evaluation indexes}

The weight is the relative importance of each index in the index system. Scientific and reasonable determination of the weight for each index in the evaluation system is the key to deciding whether the evaluation results can reflect the real situation. The weights are generally determined by the acquaintance of the importance of evaluation indexes of index system by personal experience, such as analytic hierarchy process (AHP), entropy weight method and expert consultation method (Delphi) etc. The index system of well-off water conservancy has the following features such as a simple structure and clear hierarchy. So, the method of AHP and Delphi are mainly used to determine the weights of indexes. First, index weights are calculated by AHP on the basis of the principle of "mandatory index $>$ assessment index $>$ reference index". And then after several experts consult, the weights are finalized. This method not only embodies the expertise, but also reduces the arbitrariness of subjective judgments to some extent. The weights are given in Table 1.

\section{EVALUATION METHODS}

\subsection{Data standardization}

To facilitate comparative analysis and eliminate incommensurability caused by the dimensionless indifferences, the standardization method was used to process the raw data.

(a) For positive indexes, using the formula: $C_{i}=\frac{Z_{i}}{Z_{i 0}}$

(b) For inverse indexes, using the formula: $C_{i}=\frac{Z_{i 0}}{Z_{i}}$

Note: For positive indexes, a higher value is better; for inverse indexes, a lower value is better. $C_{i}$ is the standardization value of the index; $Z_{i}$ is the present value of the index; $Z_{i 0}$ is the target value of the index.

\subsection{Comprehensive evaluation}

According to the realization degree and the corresponding weights of 37 indexes, the score of each index is calculated. Then the comprehensive score of the evaluated region is finally obtained by accumulating the score of each index. The calculation formula is as follows:

$$
H=\sum_{i=1}^{37} K_{i} C_{i} \times 100
$$

$H$ is the score; $C_{i}$ is the realization degree of the index; $K_{i}$ is the corresponding weight of the index.

\subsection{Evaluation standards of well-off water}

To evaluate whether an area can achieve well-off water or not, scientifically and objectively, two factors should be grasped: the overall level of water development, and the balance of development between each system and each index. In this study, the evaluation standards of well-off water are determined by the overall level and the single index. So the evaluation standards are based on the index types and the overall goal of well-off water in Yunnan Province.

(a) The composite score of well-off water should reach 90 points or more.

(b) Indexes are divided into mandatory indexes, assessment indexes and reference indexes, among which mandatory indexes have to reach 100 points, assessment indexes need to reach 90 points or more while the reference indexes have no requirement.

\section{EVALUATION OF WELL-OFF WATER PRESENT SITUATION}

Taking 2011 as the base year, the appraisal of the well-off water conservancy development level was carried on in Yunnan Province. Because there are some indicators in the index system only reflecting the completion of well-off water planning in the planning year, the evaluation index 
systems of the present year and planning year are different (new effective irrigation area, the rate of reservoir dredging and other 11 indexes are not participate in the present situation evaluation).

The evaluation result for the present level is shown in Fig. 2. Through calculation, the present level of well-off water in 2011 is 71 points. However, there is a certain gap to achieve the well-off water. According to the results of the assessment, the status of water source protection and river health security reached 80 points, ranking first in the six systems; water management capacity is just 40.8 points, ranking last in the six systems; flood control and drought relief mitigation ability, ability of reasonable allocation of water resources, the level of water highly effective utilization and water development security level have $70-80$ points.

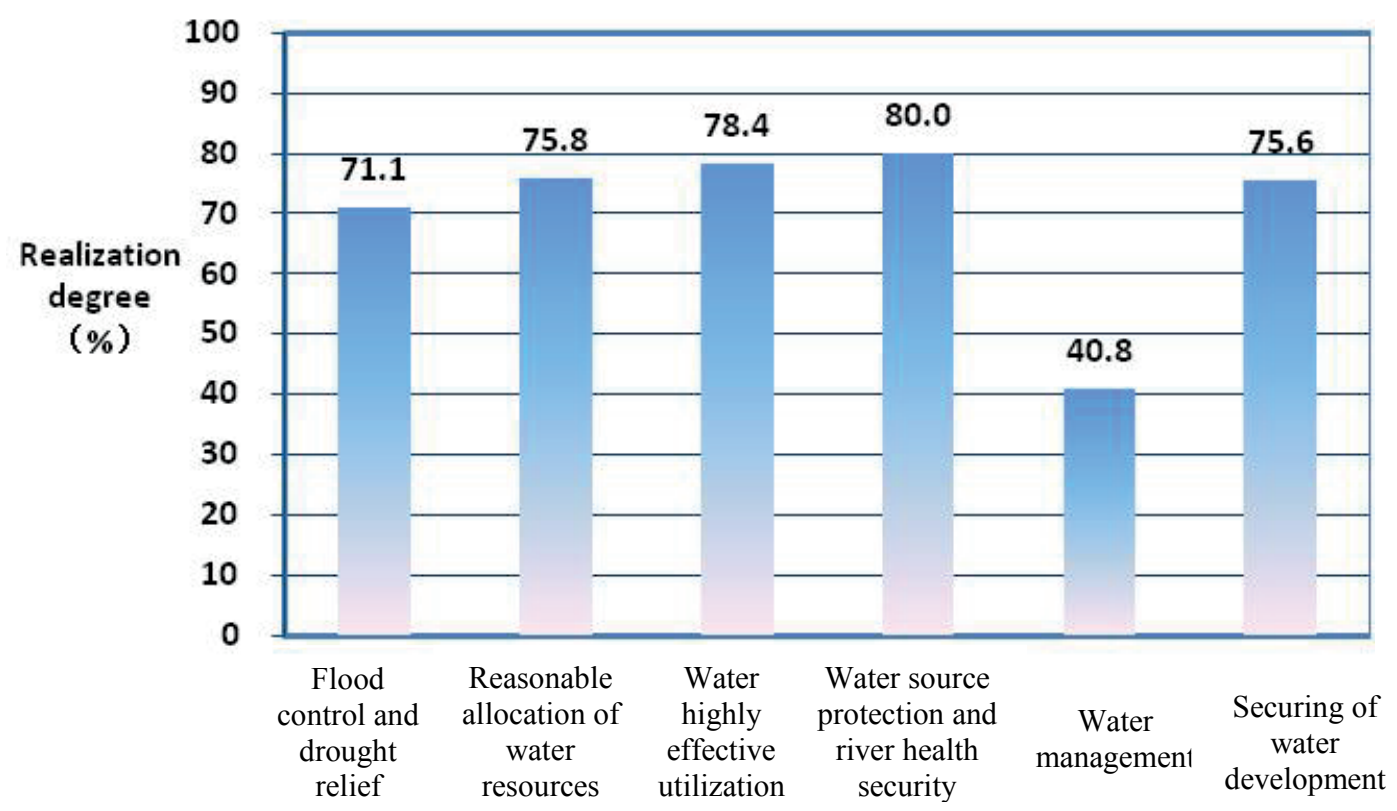

Fig. 2 Evaluation result of present level for six systems in 2011 of Yunnan.

\section{CONCLUSIONS}

(a) Well-off water is a stage goal of water modernization. Evaluation of well-off water is a complex engineering problem. To achieve an accurate evaluation of the development level of well-off water, specific evaluation indexes, reasonable target values and index weights should be determined according to the local water conservancy development status and the water conservancy construction key.

(b) In this study, the indexes are divided into mandatory, assessment, reference types. In addition, it runs through the determination of target values, weights and evaluation standards and makes the evaluation system more scientific and reasonable, with a certain degree of originality.

(c) Taking 2011 as the base year, the appraisal of the well-off water conservancy development level was made in Yunnan Province. The results show that there is a certain gap to achieve the well-off water. The status of water source protection and river health security is good while water management capacity is poor. Moreover, the evaluation results are consistent with the actual situation of Yunnan Province.

Acknowledgement This research was supported by National Natural Science Foundation of China grants (41172203).

\section{REFERENCES}

Cong, F. and D.Y. (2011) Sustainable evaluation of urban water resources and environment complex system in north coastal cities. Procedia Environment Science 11, 789-802.

Ding et al. (2006) Preliminarv study on evaluation index system of rural water conservancy modernization. China Rural Water and Hydropower 9, 74-76. 
Fu, C. et al. (2002) Connotation and evaluation index system for water conservancy modernization. Advance in Water Science 13(4), 502-506.

Li, X. et al. (2005) Studv on evaluation index system of rural water conservancy modernization in Shandong. Water Resources Development Research 5(5), 23-25, 29.

$\mathrm{Ou}$, J. and Cheng, J. (2012) Evaluation index system of Jiangsu water modernization. Journal of Irrigation and Drainage 31(5), $12-15$.

Song, L. (2010) System and evaluation of China's well-off society standards. Social Sciences in Nanjing 1, 6-14.

Tong, K. et al. (2012) Studies on assessment indicator system of modernization. China Water Resources 11, 14-18.

Xie, B. and Gu, S. (2012) The twelfth five-year plan of water-saving society in Yunnan, Bureau of Yunnan province, Yunnan.

Zhang, L. and Jia, S. (2004) The application of main component in index system construction for country water conservation modernization. Journal of Capital Normal University (Natural Science Edition) 25(1), 66-70, 80. 